\title{
THE USE AND ARTISTIC FEATURES OF XUANZI POLYCHROME PAINTING IN THE MING AND QING DYNASTIES
}

\begin{abstract}
Annotation: In the field of the pictorial decoration of Chinese architecture, the decor of the period of the Ming and Qing dynasties is considered the most outstanding since, at that time, the technique was perfect, and the methods of decoration were rich in their diversity, which was not possible in previous eras. The polychrome painting of official buildings during the Ming and Qing dynasties' reign is quite different from the Song dynasty's polychrome painting. The transition from the Song dynasty's polychrome painting to the Ming and Qing dynasties' polychrome painting was completed during the Yuan dynasty's reign. Due to the decrease of dougong in size in the Ming dynasty, polychrome painting began to be placed on beams. Xuanzi polychrome painting, which originated from painting beams under the Yuan dynas-
\end{abstract}

In the field of the pictorial decoration of Chinese architecture, the decor of the period of the Yuan, Ming, and Qing dynasties is considered the most outstanding since, at that time, the technique was perfect, and the methods of decoration were rich in their diversity, which was not possible in previous eras. The painting of buildings is the most characteristic among the types of pictorial decoration.

General State of Polychrome Painting in the Ming and Qing Dynasties.

The polychrome painting of official buildings during the Ming and Qing dynasties' reign is quite different from the Song dynasty's polychrome painting. The transition from polychrome painting in the Song dynasty to polychrome painting in the Ming and Qing Dynasties was completed during the Yuan dynasty due to aesthetic, cultural, and architectural reasons. Speaking about the general system of pictorial decoration, we can say that the Yuan dynasty's polychrome painting was a continuation of the Song dynasty's polychrome painting. Dougong was still considered a significant part of the decoration. However, compared with the ty, became the primary type. By the Qing dynasty, Hexi polychrome painting and Suzhou polychrome painting, which evolved from the folk polychrome painting of the Jiangnan region of the Ming dynasty, appeared. The Xuanzi type was one of the three main polychrome painting types in the Qing dynasty. It was fully developed compared to the Hexi type as it was used more widely. The article explains the development of the artistic features of the various decorative parts of Xuanzi polychrome painting during the Ming and Qing dynasties, the characteristics of each gradation, and the method of distinguishing it, as well as its place of application.

Keywords pictorial decoration, Xuanzi polychrome painting, Ming and Qing dynasties, architectural decor

Song dynasty, there were quite a few polychrome painting varieties and ranks. The gradation is not entirely clear during the Yuan dynasty judging by dougongs that have survived to the moment and which were found during archaeological excavations. Due to the decrease of dougong in size during the Ming dynasty, polychrome painting began to be placed on beams. This type of polychrome painting originated from the painting of beams during the Yuan dynasty and was called Xuanzi (which means polychrome painting in the form of curls). Xuanzi polychrome painting had a strict gradation, which manifested itself in decorative ornaments, colors, the amount of gold used, as well as in the place of application, and so on. By the period of the Qing dynasty, the varieties of polychrome painting increased to some extent; Hexi polychrome painting and Suzhou polychrome painting appeared, which originated from the folk polychrome painting of the Jiangnan region during the Ming dynasty. The gradation of such painting was more detailed as it was closely related to the development of the centralization of power in feudal society. 
The Development and Artistic Features of Polychrome Painting

Xuanzi polychrome painting (in the form of curls) is one of the primary forms of polychrome painting during the reign of the Ming and Qing dynasties. The initial form of Xuanzi polychrome painting can be traced back to the depictions of the form of the Ruyi scepter head in the polychrome painting of the Song dynasty beams.

By the period of the Yuan dynasty, this form had already possessed the main distinctive features of Xuanzi polychrome painting, which existed in subsequent eras. The period of the Ming dynasty is the period of standardization of Xuanzi polychrome painting. Each component and its overall composition was formed at that time. The general composition of Xuanzi painting included three main components: zhaotou, fangxin, and hezi. On both sides of the hezi element, on the left and right sides, there was a decorative gutou element (a section in the form of vertical stripes on both sides of which there was a thin outline of edging). In some periods, there was also an auxiliary gutou (unlike the main gutou, there was no edging on both sides of the auxiliary gutou) in the hezi part, on one side of the gutou, located next to the column. The zhaotou element is the central decorative pattern of Xuanzi polychrome painting, which consists of several components in the form of a winding flower. The most common combination of such a decorative ornament is "one whole (flower) and two broken ones" (that is, the decorative ornament consists of one whole flower and two half ones, which were depicted with their backs to each other).

During the reign of the Ming and Qing dynasties, the image of a winding flower had differences. Until the beginning of the middle period of the Ming dynasty, the winding flower was depicted in the form of bao-xiang flowers, which were a spindle shape with a clear beginning and end, and consisted of a core and petals. In the heart of the flower, there were five types of decorative ornaments with various shapes, namely, realistic images of flowers and herbs, the head of the Ruyi scepter, a pattern in the form of petals, a chanwen (ornament in the form of a cicada), petals in the shape of phoenix wings. Two rows of petals surrounded the core of the flower. In the inner loop, the flower's petals were depicted as round or in the form of phoenix wings, and in the outer loop, the petals took a round shape. The horizontally lying petals of two winding flowers had two sides of rotation. The triangular-shaped area, which was formed between the petals of the outer loop, was called "linjiaodi" (facets), and the presence or absence of gilding in this area was an essential criterion for determining the rank and structure of the polychrome painting.

During the middle and late period of the Ming dynasty, the image of bao-xiang flowers became scarce. An arc line gradually replaced their outer contour, and the general appearance began to acquire an almond shape. The core of the flower was also simplified and depicted in the form of a circle; however, the patterns in the inner part of the core began to differ. The shape of the petals was gradually standardized, the petals of the inner loop were depicted in an almond shape, and a black line appeared in the middle of the petal called "heilao". The petals of the outer loop were represented in the form of a neat circle that encircled the petals of the inner loop.

During the Qing dynasty's reign, the decorative ornament in the form of a winding flower was inherited and continued to develop. The outer contour of the decoration gradually acquired the rectilinear shape of a hexagon. The central ornament in the form of a winding flower and two additional flowers, located in the middle of the zhaotou element, were separated by one or two loops of petals.

In the general form of Xuanzi polychrome painting during the Qing dynasty, there were no profound or radical changes. There was a slight difference only in individual decorative ornaments. In the early period of the Qing dynasty, the winding flower in Xuanzi polychrome painting was a decorative ornament with an increased number of loops with petals (from three to five loops). Each loop contained a relatively large number of petals closely spaced to each other. The petals of the outer loop were round, and the two loops located inside the outer one were simplified and also had the shape of a circle; the petals could only be distinguished along the contour lines. In the middle and late Qing dynasty, the number of loops with petals was reduced.

The general appearance also tended to be simplified. The winding flowers strictly corresponded to the established standard and looked very formulaic. Due to the fact that the length of different structural elements was not the same, and the thickness was relatively fixed, the length of the zhaotou was also variable in the conditions of dividing the composition of the polychrome painting of the Qing dynasty 
into three parts. Therefore, based on the elemental composition of the zhaotou decorative element "one whole loop, two broken ones", decorative elements of gousyao and xixiangfeng (literally: joyful meeting) were formed. They consisted of one whole and two broken flowers with the addition of the element of the "golden Taoist cap"; of one whole and four broken flowers; of two whole and four broken ones, and so on.

The fangxin part of Xuanzi polychrome painting is a decorative element, second only to the zhaotou element in decoration. Both ends of the fangxin part, located next to the zhaotou, were depicted in different forms at different times. In the early period, there was a form of "one wave, three bends" (that is, one end of the fangxin part consisted of three concave arched lines, similar in shape to a wave, from top to bottom). From the middle period of the Ming dynasty to the early Qing dynasty, the "one wave, three bends" shape was replaced by the "head of a precious sword" shape (straight lines replaced the three concave arcuate lines). In the middle period of the Qing dynasty, the shape of the "head of a precious sword" changed to the shape of petals, consisting of one large petal and two small ones. And finally, in the late period of the Qing dynasty, "haitan hezi" standard was established. It had an arched shape and consisted of three sections. In the fangxin element area, there was a contoured frame called "lengxian" (literary: an outline of the protrusion). Until the middle period of the Ming dynasty, the lengxian outline frame was depicted with a multilevel gradation technique since this effect was an old tradition of using the gradation edging line in the polychrome painting of the Song dynasty.

In the early Ming dynasty, the inner part of fangxin of official Xuanzi polychrome painting was only covered with color without decorative ornaments. After the end of the middle period of the Ming dynasty, decorative ornaments depicting a dragon, patterns representing brocade, patterns in the form of one hieroglyph began to appear in the inner part. After the middle period of the Qing dynasty, patterns representing brocade began to be depicted only in the basic form, namely, representing a turtle shell (with hexagonal sectors).

The hezi element is another important decorative element in Xuanzi polychrome painting. Hezi refers to a square area that is placed at both ends of a wooden structure next to a zhaotou part. In the early period, a part of hezi was depicted in the form of a long rectangle, and after the end of the middle period of the Ming dynasty, the shape of hezi changed to a square. The hezi element was separated from zhaotou by using the main or auxiliary part of gutou. In the early period of the Ming dynasty, the main decorative ornaments of the hezi element of Xuanzi polychrome painting were three main patterns, namely, patterns in the form of a persimmon stem, syhe clouds (the decoration consisted of a cross of four clouds in the form of a head of the Ruyi scepter) and sychu petals (in the form of phoenix wings)...

Many other variations arose by adding petals to winding flowers, petals in the form of phoenix wings, and other ornaments. In the early Ming dynasty, the hezi element with a decorative pattern in the form of a persimmon stalk was most commonly used. From the early to middle Ming dynasty, hezi with sychu petals in the shape of phoenix wings was the most common.

The popularity of the decorative pattern in the form of syhe clouds, on the other hand, covered a reasonably long period. In general, the decorative ornaments of the hezi element were relatively simple until the middle period of the Ming dynasty, and only later were depicted in a more complex form. Except for basic decorative ornaments, the hezi element was decorated with winding flower petals.

In the period from the Middle Ming to the early Qing, an ornament in the form of a winding sychu flower was also used in addition to the three main decorative ornaments. The hezi element with Sanskrit letters was also used on some special structures, for example, in Tibetan halls (which are also called the hall of sutras; in Chinese, "tsang" means not only Tibet but also sutras; translated from Sanskrit it means a "Buddhist canon" - and the hall of sutras is the hall for storage of Buddhist canons) of the Buddhist monastery Zhihua-si, located in Beijing. During the Ming dynasty, such decorative ornaments had a relatively strict geometric division. During the Qing dynasty, the hezi element with symmetrical decorative ornaments was called "syhezi" (the hieroglyph "sy" means death, it must have meant "hezi, set tightly"), and the hezi element with more loose decorative ornaments was called "hohezi" (the hieroglyph "ho" means life, that is, the opposite of the fixed hezi, the movable hezi). During the Qing dynasty, the main syhezi decorative ornaments were a gardenia flower pattern, a cruciform pattern, and syhe clouds. The design in the form of a gardenia flower was subdivided into two types: a solid flower 
(that is, a solid pattern in the form of a gardenia flower was placed in the center of hezi) and a broken flower (the whole area of hezi is divided into four triangular parts in accordance with the diagonal lines, each of which depicts a half gardenia flower). The gardenia broken flower pattern was practically not used until the middle period of the Qing dynasty. The cruciform design implied a decorative ornament filled with winding petal flowers, in the center of which a cross was depicted.

During the Ming dynasty's reign, similar ornaments already existed; however, this ornament was carried out only during the Qing dynasty. A diamond-shaped area formed from curved lines was on the top of hohezi. In this area, decorative ornaments in the form of a dragon, a phoenix, a one-legged dragon Kui, patterns in the form of flowers and herbs, vajras, and many other ornaments were depicted, which were mainly used in Xuanzi polychrome painting of the highest rank.

In addition to the basic elements zhaotou, fangxin, and hezi, the gutou element, which has a division function, had various forms during the reigns of different dynasties. First of all, the gutou element was subdivided into auxiliary gutou and main gutou. The auxiliary gutou was located in the place of the element at the ends of columns and was also the beginning of the composition of Xuanzi polychrome painting. The auxiliary gutou, as the beginning of the Xuanzi composition, began to be used from the Yuan dynasty to the Qing dynasty during Kangxi rule. By the reign of Emperor Shunzhi of the Qing dynasty, the main gutou began to be used as the beginning of the composition, which gradually became the tradition of Xuanzi polychrome painting of the Qing dynasty. Unlike the main gutou, the auxiliary gutou was usually only covered with color, without the image of decorative ornaments. The main gutou of the Qing dynasty was subdivided into hogutou and sigutou (similarly to hohezi and syhezi). Hogutou was commonly used with high-grade Xuanzi polychrome painting. Behind two contour lines, decorative ornaments were also depicted, for example, an ornament of happiness and longevity, an ornament in the form of a swastika, as well as a kind of ring gutou (that is, perpendicular lines placed in a row were used to create the base, and the pattern in the form of rings was formed due to the intersection of lines)... The spread of the hogutou element began in the middle period of the Qing dynasty. Only color coverage was used in the early period, and a sygutou in the form of a single black line was depicted in the middle.

The periodization of individual eras of Xuanzi polychrome painting can be assessed by three main aspects: the use of gutou as the beginning of the composition, the core of winding flowers, and the shape of both ends of the fangxin element. Detailed information can be found in work "Study of the Periodization, Form, and Structure of Polychrome Painting in the Imperial House of the Ming and Qing Dynasties" [1], written by researcher Cao Zhenwei on the polychrome painting of the Forbidden City.

Periodization of Xuanzi Polychrome Painting.

Polychrome painting of the Ming and Qing dynasties can be divided into polychrome painting from the highest to the lowest rank depending on the color of the coating, the amount of gold used, and the use of the gradation technique and other features.

During the reign of these dynasties, for the use of polychrome painting of a certain rank, it was required to match the status of an architectural structure, that is, if polychrome painting of different ranks was used in the structures of one architectural ensemble, then the rank of the polychrome painting of the main architectural structure was one of the critical factors that determine the rank of the architectural ensemble. First of all, during the existence of the Ming and Qing dynasties, type A polychrome painting was the painting of the highest rank (not only among the types of Xuanzi polychrome painting but even higher than Hexi polychrome painting of the Qing dynasty). The scope of such painting was extremely limited since it could be observed only in two palace halls for worshiping ancestors, namely in the Temple of the Imperial Ancestors of the Ming dynasty and in the Palace Hall for Honoring the Ancestors of the Qing dynasty (there is another specific case during the Ming era, the use of it on the Umen Gates). Before the appearance of Hexi polychrome painting in the Qing dynasty, polychrome painting of type B1 was used in palace halls. It was considered painting of a high rank, which was second only to painting of type A. Such painting could be seen only in the palace architecture of the Ming dynasty, namely in Nanxun Hall of the Forbidden City. Perhaps this was due to the engraved portraits of empresses, which were once collected by court officials. Since the polychrome painting was higher in rank than Xuanzi painting, during the reign of the Qing dynasty, type B1 polychrome painting was mainly used in 
high-rank annexes located in palace halls, religious buildings, such as the Xuanqiong Buddhist Hall, the side hall of the Shoukan Palace.

Type B2 polychrome painting was used only in the architecture of the Qing dynasty. It was mainly used in high-rank Buddhist monasteries and aboveground structures in the tombs of emperors and empresses. The use of polychrome painting types $\mathrm{C} 1, \mathrm{C} 2$ of the Ming dynasty, as well as polychrome painting C1-C3 of the Qing dynasty was the most extensive. During the reign of these two dynasties, most of them were used in monasteries and palace halls of the middle and higher ranks. Polychrome painting type D1 was widely used in the early period of the Ming dynasty when the gradation of polychrome painting was not entirely clear, and during the Qing dynasty, it was intended only for low-rank outbuildings.

And finally, the polychrome painting type D2. Even though the polychrome painting of type D2, similar to type D1, belonged to the low-rank painting, both of them practically did not differ. Their difference was only in the place where painting was used. These types of painting were mainly intended for the "sacred kitchen" (a room for cooking things planned for sacrifices) of non-religious places of worship, the Zaisheng pavilion (a pavilion for the slaughter of sacrificial animals), and other low-rank structures.

\section{Conclusion}

Generally speaking, Xuanzi polychrome painting of the Ming and Qing dynasties experienced the development of decorative ornaments from their free variety to establishing a single standard. The overall result - from simple to complex, from modest to luxurious. The classification of the polychrome painting by rank gradually began to be detailed. Besides, the polychrome painting of the two dynasties was strongly influenced by various factors, such as the social economy, cultural atmosphere, and the aesthetic perception of the ruling class.

\section{REFERENCES}

1. History of Ancient Chinese Architectural Science and Technology. Research Institute of the History of Natural Sciences of the Chinese Academy of Sciences. Beijing: Scientific Press, 1985. (中「科「院自然科「史「究所.中「古 代建筑技「史//北京：科「出版社， 1985)

2. Jiang Guangquan. 2005. Chinese Official Architectural Polychrome Painting of the Qing Era. Beijing: Chinese Architecture Publishing House, 2005. ( $「$ 广全.中 $\ulcorner$ 代官 式建筑彩「技「//北京: 中「建筑工「出版社, 2005)

3. Bian Jingyi. 2007. Polychrome Lacquer Painting of Buildings in Ancient China. Beijing: Chinese Architecture Publishing House, 2007. ( 「精一.中「古建筑油漆彩「// 北京：中下建筑工「出版社，2007）

4. Yang Hong, Ji Lifang. 2016. "Research on the Periods of the Official Polychrome Painting of the Ming Era on the Gugong Museum Buildings", Article of the Gugong Museum Magazine, 04.2016. ( $\ulcorner\ulcorner$, 「立芳.紫禁 城「存明代官式彩 $「$ 分期探 $「 / /$ 故「博物院院刊 04.2016)
5. Cao Zhenwei. 2017. "Research on Individual Eras of the Imperial Xuanzi Polychrome Painting of the Ming and Qing Dynasties", Collection of the Gugong Museum, 04.2017. (曹振「. 明「皇家旋子彩「形制分期「究 //故「博物院院 刊: 04.2017)

6. Peng Mei. 2013. "Research of the Official Architectural Polychrome Painting in the Early Ming Dynasty", Master's Thesis, China Northern Technical University. (彭梅. 明 早期官式彩「「究//「士「文：北方工「大「，2013） Notes

7. 1. Cao Zhenwei. "Research on Individual Eras of the Imperial Xuanzi Polychrome Painting of the Ming and Qing Dynasties" // Collection of the Gugong Museum, 04.2017. (曹振「. 明「皇家旋子彩「形制分期「究 //故「博物院 院 刊：04.2017) 


\section{ИСПОЛЬЗОВАНИЕ И ХУДОЖЕСТВЕННЫЕ ОСОБЕННОСТИ ПОЛИХРОМНОЙ РОСПИСИ СЮАНЬЦЗЫ В ЭПОХИ МИН И ЦИНЬ}

Аннотация: В области живописного декора китайской архитектуры декор периода правления династий Мин и Цин считается наиболее выдающимся, так как в те времена техника исполнения была совершенной, а методы декоративного убранства очень богаты по своему разнообразию, что не было возможно в предшествующие эпохи. Полихромная роспись официальных сооружений в период правления династий Мин и Цин достаточно сильно отличается от полихромной росписи династии Сун. Переход от полихромной росписи династии Сун к полихромной росписи династий Мин и Цин завершился в период правления династии Юань. Из-за уменьшения размера доугуна в период династии Мин полихромную роспись стали размещать на балках, а вид полихромной росписи «Сюаньцзы», который произошел от росписи балок

В области живописного декора китайской архитектуры декор периода правления династий Юань, Мин и Цин считается наиболее выдающимся, так как в те времена техника исполнения была совершенной, а методы декоративного убранства очень богаты по своему разнообразию, что не было возможно в предшествующие эпохи. Среди видов живописного декора самым характерным является роспись зданий.

Общее положение полихромной росписи в эпоху Мин и Цин.

Полихромная роспись официальных сооружений в период правления династий Мин и Цин достаточно сильно отличается от полихромной росписи династии Сун. Переход от полихромной росписи династии Сун к полихромной росписи династий Мин и Цин завершился в период правления династии Юань, что было вызвано эстетическими и культурными причинами, а также причинами, связанными с архитектурной конструкцией. при династии Юань, стал главным видом в этот период. К периоду правления династии Цин появились полихромная роспись хэси и сучжоуская, которая произошла от народной росписи региона Цзяннань периода династии Мин. Сюаньцзы является одним из трех основных видов полихромной росписи в эпоху Цин. Он получил более полное развитие, чем вид Хэси, так как использовался более широко. В этой статье объясняется эволюция художественных особенностей различных декоративных частей полихромной росписи Сюаньцзы в эпоху династий Мин-Цин, даются характеристики каждой градации и методы создания, а также место ее использования.

Ключевые слова: живописный декор, полихромная роспись сюаньцзы, эпохи Мин и Цин, архитектурный декор.

Говоря об общей системе живописного декора можно сказать, что полихромная роспись династии Юань являлась продолжением полихромной росписи династии Сун. Доугун по-прежнему считался чрезвычайно важной частью декоративного убранства, однако, судя по сохранившимся на данный момент и найденным в ходе археологических раскопок доугунам, по сравнению с династией Сун, при династии Юань разновидностей и рангов полихромной росписи было достаточно мало, а градация не совсем ясна. Из-за уменьшения размера доугуна в период династии Мин полихромную роспись стали размещать на балках. Такой вид полихромной росписи произошел от росписи балок при династии Юань и назывался сюаньцзы (т.е. полихромная роспись в виде завитков).

Полихромная роспись сюаньцзы обладала строгой градацией, которая наглядно проявлялась в декоративных орнаментах, цветовой гамме, количестве используемого золота, а также в 
месте применения и т.д. К периоду правления династии Цин разновидностей полихромной росписи в некоторой степени стало больше, появились полихромная роспись хэси и сучжоуская полихромная роспись, которая произошла от народной полихромной росписи региона Цзяннань периода династии Мин. Градация таких росписей была более детальной, что было тесно связано с развитием централизации власти феодального общества.

Развитие и художественные особенности полихромной росписи.

Полихромная роспись сюаньцзы (в виде витков) является одной из основных форм полихромной росписи в период правления династий Мин и Цин. Начальную форму полихромной росписи сюаньцзы можно проследить до изображений в виде «головки жезла жуи» в полихромной росписи балок династии Сун. К периоду правления династии Юань данная форма уже обладала главными отличительными чертами полихромной росписи сюаньцзы, которые существовали и в последующие эпохи. Период правления династии Мин является периодом стандартизации полихромной росписи сюаньцзы. Каждый компонент и общая ее композиция сформировались в то время. Общая композиция росписи сюаньцзы включала в себя три главных компонента: чжаотоу, фансинь и хэцзы. По обеим сторонам элемента хэцзы с левой и правой стороны размещался декоративный элемент гутоу (участок в виде вертикальных полосок, по обеим сторонам которых располагался тонкий контур окантовки). В некоторые периоды в части хэцзы с одной стороны гутоу, расположенной рядом с колонной, также располагался вспомогательный гутоу (в отличие от основного гутоу, по обеим сторонам вспомогательного отсутствовала окантовка).

Элемент чжаотоу является главным декоративным рисунком полихромной росписи сюаньцзы, которая состоит из нескольких компонентов в виде витого цветка. Наиболее частой комбинацией такого декоративного орнамента является «один цельный (цветок) и два ломаных» (то есть декоративный орнамент состоит из одного цельного цветка и двух половинчатых, которые изображались спиной друг к другу). В период правления династий Мин и Цин изображение витого цветка имело различия. До начала правления среднего периода династии Мин витой цветок изображался в виде цветов бао-сян, которые представляли собой форму веретена с четким началом и концом и состояли из сердцевины и лепестков. В сердцевине цветка размещались 5 видов декоративных орнаментов с разнообразной формой, а именно реалистичные изображения цветов и трав, головки жезла жуи, узор в виде лепестков, чаньвэнь (орнамент в форме цикады), лепестки в виде крыльев феникса. Сердцевину цветка окружали два ряда лепестков. Во внутреннем витке лепестки цветка изображались круглыми либо в виде крыльев феникса, а во внешнем витке лепестки принимали круглую форму. Горизонтально лежащие лепестки двух витых цветков имели две стороны вращения. Область треугольной формы, которая образовывалась между лепестками внешнего витка, называлась «линцзяоди» (грани), а наличие или отсутствие позолоты на данном участке являлось важным критерием для определения ранга и структуры полихромной росписи.

При среднем и позднем периоде династии Мин изображение цветов бао-сян стало скудным, их внешний контур постепенно сменялся дуговой линией, а общий вид стал приобретать миндалевидную форму. Сердцевина цветка также была упрощена и изображалась в форме круга, однако узоры во внутренней части сердцевины стали различаться. Форма лепестков постепенно стандартизировалась, лепестки внутреннего витка изображались в миндалевидной форме, а посередине лепестка появилась черная линия под названием «хэйлао». Лепестки внешнего витка изображались в форме аккуратного круга, который опоясывал лепестки внутреннего витка. В период правления династии Цин декоративный орнамент в виде витого цветка был унаследован и продолжил свое развитие. Внешний контур орнамента постепенно приобретал прямолинейную форму шестиугольника. Главный орнамент в виде витого цветка и двух дополнительных цветков, расположенных посередине части элемента чжаотоу, был разделен при помощи одного или двух витков лепестков.

В общем виде полихромной росписи сюаньцзы династии Цин не было столь огромных и коренных изменений, небольшая разница заключалась лишь в определенных декоративных орнаментах. В ранний период династии Цин витой цветок в полихромной росписи сюаньцзы представлял собой декоративный орнамент с увеличенным количеством витков с лепестками (от трех до пяти витков). В каждом витке находилось достаточ- 
но большое количество близко расположенных друг к другу лепестков. Лепестки внешнего витка были круглыми, а два витка, расположенных внутри внешнего, были упрощены и также имели форму круга, различить лепестки можно было только по линиям контура.

В средний и поздний период династии Цин количество витков с лепестками было уменьшено, количество лепестков каждого витка лишь отчасти. Общий вид также имел тенденцию упрощения. Витые цветки строго соответствовали установленному стандарту и выглядели весьма шаблонными. Из-за того, что длина разных элементов конструкции была неодинаковой, а толщина относительно фиксированной, вследствие этого, в условиях разделения композиции полихромной росписи династии Цин на три части, длина чжаотоу также была непостоянной. Поэтому на основании базовой композиции декоративного элемента чжаотоу «один цельный виток два ломаных», сформировались декоративные элементы гоусыяо и сисянфэн (досл. радостная встреча), которые состояли из 1 цельного и 2 ломаных цветков с добавлением элемента «золотой даосской шапки»; из 1 цельного и 4 ломаных цветков; из 2 цельных и 4 ломаных и т.д. Часть фансинь полихромной росписи сюаньцзы представляет собой декоративный элемент, который по значимости в декоре уступает лишь элементу чжаотоу. Оба конца части фансинь, расположенные рядом с чжаотоу, в разные периоды изображались в разной форме. В ранний период существовала форма «одна волна - три изгиба» (то есть один конец части фансинь сверху донизу состоял из трех вогнутых дугообразных линий, по форме схожих с волной). Со среднего периода династии Мин до раннего периода династии Цин форма «одна волна - три изгиба» была заменена на форму «головка драгоценного меча» (три вогнутые дугообразные линии были заменены на прямые линии). В средний период правления династии Цин форма «головка драгоценного меча» сменилась на форму лепестков, состоящую из одного большого лепестка и двух маленьких. И, наконец, в поздний период династии Цин был установлен стандарт под названием «хайтан хэцзы», который имел дугообразную форму и состоял из трех участков. В области элемента фансинь находилась контурная рамка под названием «лэнсянь» (досл. контур выступа). До среднего периода династии Мин контурная рамка лэнсянь изображалась с техникой многоуровневой градации, поскольку использование данного эффекта являлось старой традицией применения линии окантовки градации в полихромной росписи династии Сун.

В ранний период династии Мин внутренняя часть фансинь официальной полихромной росписи сюаньцзы только покрывалась цветом, без декоративных орнаментов. После окончания среднего периода династии Мин во внутренней части начали появляться декоративные орнаменты с изображением дракона, узоры под парчу, узоры в виде одного иероглифа, среди них узоры под парчу после среднего периода династии Цин стали изображаться только в основной форме, а именно под черепаший панцирь (с шестиугольными секторами). Еще одним важным декоративным элементом в полихромной росписи сюаньцзы является элемент хэцзы. Под хэцзы подразумевается квадратный участок, который размещается на обоих концах деревянной конструкции рядом с частью чжаотоу. В ранний период часть хэцзы изображалась в форме длинного прямоугольника, а после окончания среднего периода династии Мин форма хэцзы сменилась на квадрат. Элемент хэцзы отделялся от чжаотоу при помощи основной или вспомогательной части гутоу.

В ранний период династии Мин основными декоративными орнаментами элемента хэцзы полихромной росписи сюаньцзы являлись три главных узора, а именно узоры в виде стебля хурмы, облаков сыхэ (орнамент состоял из перекрестья четырех облаков в форме головке жезла жуи) и лепестков сычу (в форме крыльев феникса). С помощью добавления лепестков на витые цветки, лепестков в виде крыльев феникса и др. орнаментов возникло множество других вариаций. В ранний период династии Мин наиболее часто использовался элемент хэцзы с декоративным узором в виде стебля хурмы, а с раннего до среднего периода династии Мин наиболее распространенным являлся хэцзы с лепестками сычу в виде крыльев феникса.

Популярность декоративного узора в виде облаков сыхэ, напротив, охватывала достаточно большой период. В целом декоративные орнаменты элемента хэцзы до среднего периода династии Мин были относительно простыми, а уже позже изображались в более сложной форме. За исключением основных декоративных орнаментов, элемент хэцзы украшался лепестками витых 
цветков. В период от средней Мин до ранней Цин, помимо трех главных декоративных орнаментов, также применялся орнамент в виде витого цветка сычу. На некоторых особых сооружениях, например, в тибетских залах (которые еще называют зал сутр; «цзан» на китайском означает не только Тибет, но также и сутры, в переводе с санскрита это означает «буддийский канон»- а зал сутр и является залом для хранения буддийских канонов) буддийского монастыря Чжихуа-сы, расположенного в Пекине, также использовался элемент хэцзы с санскритскими письменами. При династии Мин такого рода декоративные орнаменты имели достаточно строгое геометрическое деление. Элемент хэцзы с симметричными декоративными орнаментами при династии Цин назывался «сыхэцзы» (иероглиф «сы» означает смерть, должно быть, это подразумевало собой «хэцзы, установленный намертво»), а элемент хэцзы с более свободными декоративными орнаментами назывался «хохэцзы» (иерогли $\phi$ «хо» означает жизнь, то есть противоположность установленному намертво хэцзы, подвижный хэцзы).

Основными декоративными орнаментами сыхэцзы при династии Цин являлись узор в виде цветка гардении, крестообразный узор и облака сыхэ. Узор в виде цветка гардении подразделялся на два вида: цельный цветок (то есть цельный узор в виде цветка гардении размещался в центре хэцзы) и ломаный цветок (весь участок хэцзы в соответствии с диагональными линиями разделяется на четыре треугольные области, в каждой из которых изображается половинка цветка гардении). Узор в виде ломаного цветка гардении до среднего периода династии Цин практически не применялся. Крестообразный узор подразумевал собой декоративный орнамент, заполненный витыми цветками из лепестков, в центре которого изображался крест. В период правления династии Мин уже существовали подобные орнаменты, однако действительное применение данного орнамента осуществилось лишь при династии Цин. На верхней части хохэцзы находился ромбовидный участок, сформированный из кривых линий. В данном участке изображались декоративные орнаменты в виде дракона, феникса, одноногого дракона куй, узоры в виде цветов и трав, ваджры и многие другие орнаменты, которые в основном применялись в полихромной росписи сюаньцзы высшего ранга.
Помимо основных элементов чжаотоу, фансинь и хэцзы, элемент гутоу, обладающий функцией разделения, в периоды правления разных династий имел разнообразные формы выражения. Прежде всего, элемент гутоу подразделялся на вспомогательный гутоу и основной гутоу. Вспомогательный гутоу располагался в месте элемента у концов колонн, а также являлся началом композиции полихромной росписи сюаньцзы. Вспомогательный гутоу в качестве начала композиции сюаньцзы стали применять, начиная с эпохи династии Юань до эпохи династии Цин под девизом правления Канси. К периоду правления императора Шуньчжи династии Цин основной гутоу начал использоваться в качестве начала композиции, что постепенно стало традицией полихромной росписи сюаньцзы династии Цин.

В отличие от основного гутоу, вспомогательный обычно только покрывался цветом, без изображения декоративных орнаментов. Основной гутоу династии Цин подразделялся на хогутоу и сыгутоу (аналогично хохэцзы и сыхэцзы). Хогутоу обычно использовался с полихромной росписью сюаньцзы высокого ранга. За двумя контурными линиями также изображались декоративные орнаменты, например, орнамент счастья и долголетия, орнамент в виде свастики, а также своеобразные кольцевые гутоу (то есть для создания основания использовались помещенные в ряд перпендикулярные линии, а рисунок в виде колец формировался за счет пересечения линий). Распространение элемента хогутоу началось в средний период династии Цин. В ранний период использовалось только покрытие цветом, а посередине изображался сыгутоу в виде одной черной линии.

Периодизацию отдельных эпох полихромной росписи сюаньцзы можно оценивать по трем главным аспектам: использование гутоу в качестве начала композиции, сердцевина витых цветков, форма обоих концов элемента фансинь. Подробную информацию можно изучить в работе «Исследование периодизации, формы и структуры полихромной росписи императорского дома династий Мин и Цин» [1], написанной исследователем Цао Чжэньвэй о полихромной росписи музея Гугун.

Периодизация полихромной росписи Сюаньцзы.

Полихромную роспись династий Мин и Цин в зависимости от цвета покрытия, количества ис- 
пользуемого золота и применения техники градации и других особенностей можно подразделить на полихромную роспись от высшего до низшего ранга.

В период правления данных династий для использования полихромной росписи определенного ранга требовалось соответствие ранга архитектурного сооружения, то есть, если в сооружениях одного архитектурного ансамбля использовалась полихромная роспись разных рангов, то ранг полихромной росписи главного архитектурного сооружения являлся одним из ключевых факторов, определяющих ранг архитектурного ансамбля. Прежде всего в период существования династий Мин и Цин полихромная роспись типа А являлась росписью самого высокого ранга (не только среди видов полихромной росписи сюаньцзы, но даже выше, чем полихромная роспись хэси династии Цин). Область применения такой росписи была крайне ограниченной, поскольку ее можно было наблюдать только в двух дворцовых залах для почитания предков, а именно в Храме императорских предков династии Мин и во Дворцовом зале для почитания предков династии Цин (есть еще один специфический случай при эпохе Мин, использование на воротах Умэнь. Полихромная роспись типа В1 до появления в династии Цин полихромной росписи хэси применялась во дворцовых залах и считалась росписью высокого ранга, которая по значимости уступала лишь росписи типа А. Такую роспись можно было увидеть лишь во дворцовой архитектуре династии Мин, а именно в зале Наньсюнь Запретного города. Возможно, это было связано с гравированными портретами императриц, которые когда-то коллекционировали придворные чиновники. Так как полихромная роспись по рангу была выше, чем роспись сюаньцзы, то в период правления династии Цин полихромная роспись типа В1 в основном использовалась в пристройках высокого ранга, расположенных во дворцовых залах, религиозных сооружениях, например, в буддийском зале Сюаньцюн, боковом зале дворца Шоукан. Полихромная роспись типа В2 наблюдалась только в архитектуре династии Цин и в основном применялась в буддийских монастырях высокого ранга, а также надземных сооружениях в гробницах императоров и императриц. Применение полихромной росписи типа С1, C2 династии Мин, а также полихромной росписи С1-С3 династии Цин было наиболее обширным. В пе- риод правления двух этих династий в большинстве своем они использовались в монастырях и дворцовых залах среднего и высшего ранга. Полихромная роспись типа D1 имела достаточно широкое применение в ранний период правления династии Мин, когда градация полихромной росписи оставалась не совсем четкой, а в период правления династии Цин предназначалась только для пристроек низкого ранга. И, наконец, полихромная роспись типа D2. Несмотря на то, что полихромная роспись типа D2, схожая с типом D1, относилась к росписи низкого ранга, и та и другая практически не отличались, их разница заключалась лишь в месте применения росписи. Эти типы росписи главным образом предназначались для «священной кухни» (комната для варки вещей, предназначенных для жертвоприношений) нерелигиозных культовых сооружений, павильона Цзайшэн (павильон, предназначенный для закалывания жертвенных животных) и для других сооружений низкого ранга.

\section{Заключение}

Говоря в целом, полихромная роспись сюаньцзы династий Мин и Цин пережила процесс развития декоративных орнаментов от их свободного многообразия до установления единого стандарта, общий результат - от простого до сложного, от скромного до роскошного, а классификация полихромной росписи по рангам постепенно стала детализироваться. Помимо этого, полихромная роспись двух династий подверглась сильному влиянию различных факторов, таких как социальная экономика, культурная атмосфера и эстетическое восприятие господствующего класса. 


\section{БИБЛИОГРАФИЯ}

1. История древней китайской архитектурной науки и техники / НИИ истории естественных наук Китайской академии наук. - Пекин: Научный пресс,1985 (中「科「院自然科「史「究所.中「古代建筑技「史//北京： 科「出版社, 1985)

2. Цзян Гуанцюань. Китайская официальная архитектурная полихромная роспись эпохи Цин. Пекин: Издательство «Китайская архитектура», 2005 (「广全.中「「代官式建筑彩「技「//北京：中「建筑工「出 版社, 2005)

3. Бянь Цзинъи. Лаковая полихромная роспись зданий древнего Китая. - Пекин: Издательство «Китайская архитектура», 2007 (「精一.中「古建筑油漆彩「//北京 : 中「建筑工「出版社, 2007)

4. Ян Хун, Цзи Лифан. Исследование по периодам официальной полихромной росписи эпохи Мин на зданиях музея Гугун // Статья журнала «Музей Гугун». -2016/4（「「, 「立芳.紫禁城「存明代官式彩「分 期探「//故「博物院院刊 04.2016)

5. Цао Чжэньвэй. Исследование по отдельным эпохам императорской полихромной росписи сюаньцзы эпох Мин и Цин // Сборник Музея Гугун. - 2017/4 (曹振「. 明「皇家旋子彩「形制分期「究 // 故「博 物院 院 刊 : 04.2017)

6. Пэн Мэй. Исследование официальной архитектурной полихромной росписи в ранний период династии Мин / Диссертация магистра, Китайский северный технический университет, 2013 (彭梅. 明 早期 官 式彩「「究 //「土「文：北方工「大「， 2013） 